University of Nebraska - Lincoln

DigitalCommons@University of Nebraska - Lincoln

$10-2011$

\title{
Tools for managing invasions: acceptance of non-toxic baits by juvenile Nile monitor lizards and Burmese pythons under laboratory conditions
}

\author{
Peter J. Savarie \\ USDA, National Wildlife Research Center \\ Richard M. Engeman \\ USDA-APHIS-Wildlife Services, s_r100@yahoo.com \\ Richard E. Mauldin \\ United States Department of Agriculture, Richard.E.Mauldin@usda.gov \\ Tom Mathies \\ U.S. Department of Agriculture, Animal Plant Health Inspection Service, tom.c.mathies@usda.gov \\ Kenneth L. Tope \\ USDA, National Wildlife Research Center
}

Follow this and additional works at: https://digitalcommons.unl.edu/icwdm_usdanwrc

Savarie, Peter J.; Engeman, Richard M.; Mauldin, Richard E.; Mathies, Tom; and Tope, Kenneth L., "Tools for managing invasions: acceptance of non-toxic baits by juvenile Nile monitor lizards and Burmese pythons under laboratory conditions" (2011). USDA National Wildlife Research Center - Staff Publications. 1314. https://digitalcommons.unl.edu/icwdm_usdanwrc/1314

This Article is brought to you for free and open access by the U.S. Department of Agriculture: Animal and Plant Health Inspection Service at DigitalCommons@University of Nebraska - Lincoln. It has been accepted for inclusion in USDA National Wildlife Research Center - Staff Publications by an authorized administrator of DigitalCommons@University of Nebraska - Lincoln. 


\title{
Tools for managing invasions: acceptance of non-toxic baits by juvenile Nile monitor lizards and Burmese pythons under laboratory conditions
}

\author{
Peter J. Savarie, Richard M. Engeman*, Richard E. Mauldin, Tom Mathies and Kenneth L. Tope \\ USDA, National Wildlife Research Center, 4101 LaPorte Ave, Fort Collins, CO 80521-2154, USA
}

(Received 10 February 2011; final version received 9 June 2011)

\begin{abstract}
Nile monitor lizards (Varanus niloticus) and Burmese pythons (Python molurus bivittatus) are large, invasive, predatory reptiles, which are now well established in south Florida. Acetaminophen was recently shown to be lethal to both animals and therefore has potential for inclusion in an integrated pest management effort to control these species. However, acceptable bait matrices for both species are still needed to deliver the toxicant. We tested nine candidate bait matrices on juvenile Nile monitor lizards and Burmese pythons in the laboratory. Baits were tested fresh and also after aging at $30^{\circ} \mathrm{C}$ and $50 \%$ relative humidity for $24 \mathrm{~h}$. Six of the nine baits were well accepted by the monitors in both fresh and aged conditions (dead neonatal mouse, dead quail chick, ground turkey, chicken liver, tilapia, and zebra finch egg). Only the fresh dead neonatal mouse and fresh dead quail chick were well accepted by the pythons. As far as we are aware, these tests are the second of such bait matrix preference tests conducted for reptiles. The implications of our results are discussed regarding further development and testing of baits in a natural setting.
\end{abstract}

Keywords: integrated pest management; invasive species; Python molurus bivittatus; toxicant delivery; Varanus niloticus

\section{Introduction}

A large number of exotic reptilian species have successfully established invasive populations in Florida (Meshaka et al. 2004; Meshaka 2006). In fact, the number of non-native (exotic) lizard species breeding in Florida now exceeds the number of native species by more than threefold in south Florida (Hardin 2007). Prominent among the many invasive reptile species is the Nile monitor (Varanus niloticus [L.]) and the Burmese python (Python molurus bivittatus Kuhl). Both species are large; the Nile monitors may attain lengths of $2.3 \mathrm{~m}$ (Enge et al. 2004) and Burmese pythons may reach $7 \mathrm{~m}$ (Minton and Minton 1973).

Since first being recorded in 1990, the Nile monitor has become firmly established in the Cape Coral area of Lee County (Enge et al. 2004). It now also appears to have become established in the Homestead Air Reserve Base area, has been observed in at least five other counties, and may well be established elsewhere in Florida (Florida Fish and Wildlife Conservation Commission 2011; USDA/Wildlife Services, unpublished data). In the USA, Nile monitors have been commonly sold in the pet trade (Bayless 1991; Faust 2001), although the size and behavioral disposition of the adults makes them ill-suited as pets (Bennett 1995). Its range around Cape Coral has been expanding into neighboring wildlands, including nearby Pine Island and Sanibel Island where it would be a threat to endangered sea turtles and shore birds (Enge et al. 2004; Campbell 2005).

The Nile monitor can rapidly outgrow many, if not most, of its potential predators (Meshaka 2006). This large-bodied carnivore feeds on insects, arachnids, molluscs, fish, amphibians, reptiles, birds, mammals, and carrion (Bennett 2002; Lenz 2004). It is capable of eating a wide variety of vertebrate prey, and has the potential to adversely affect a number of threatened and endangered species in the process (Meshaka 2006). For example, the burrowing owl (Athene cunicularia), a Florida Species of Concern, has already been observed as a prey item (Hardin 2007). The Nile monitor is also a prolific species, capable of reaching high population densities (Western 1974).

The Burmese python is a large invasive constrictor snake that is well established in southernmost Florida (Meshaka et al. 2000, 2004; Snow et al. 2007b). As with the Nile monitor, the species' invasion pathway in south Florida has been largely attributed to (illegal) pet releases, although the highly destructive Hurricane Andrew in 1992 may have released many from captive breeding and holding facilities (Snow et al. 2007b; Bilger 2009). The Burmese python is a generalist carnivore, consuming primarily mammals and birds, but also reptiles, amphibians, and fishes (Snow et al. 2007b). Ecological impacts of Burmese pythons in south Florida continue to be identified, with 
documented predation on many native species, including endangered species (Greene et al. 2007; Snow et al. 2007a). Placing their depredations in economic contexts has revealed economic benefits for addressing the problem (Smith et al. 2007).

Some accumulation of information for the management of both species has begun (e.g. Campbell 2005; Mauldin and Savarie 2010). Building on the successful development of acetaminophen as a toxicant for brown tree snakes (Savarie et al. 2001), laboratory trials showed acetaminophen to also be effective for juvenile Nile monitors and Burmese pythons (Mauldin and Savarie 2010).

Development of control tools and strategies for Burmese pythons is in its infancy and will likely follow similar conceptual approaches that have been successful against invasive brown tree snakes (Boiga irregularis) on Guam (Engeman and Vice 2001). Research has been implemented by multiple agencies and universities into technologies and strategies for controlling Burmese pythons, including capture mechanisms, detection methods, reproductive vulnerabilities, chemical cues, and toxicants (Snow et al. 2007b; Engeman et al. 2009; Mauldin and Savarie 2010).

There are no established, systematic operational techniques available for controlling either species. Development of a number of tools and strategies will be required for the practical implementation of an effective integrated pest management effort, as was done on Guam, where toxicants have a role in controlling brown tree snakes (Engeman and Vice 2001). Similarly, toxicants could possibly play a role in controlling Nile monitor lizards and Burmese pythons. Dead neonatal mouse (DNM) baits treated with acetaminophen are effective for reducing brown tree snake populations under field conditions on Guam (Savarie et al. 2001). More recently, acetaminophentreated DNMs were found to be lethal to juvenile Nile monitor lizards and Burmese pythons under laboratory conditions (Mauldin and Savarie 2010). However, application of an acetaminophen-treated bait in the field requires identification of baits that are most highly preferred for each species. In the present study, nine commercially available candidate baits, including the DNM, were evaluated for acceptance (consumption) under laboratory conditions. Results of the present bait evaluations may identify multiple bait matrices having desirable characteristics for operational baiting of the Nile monitors and Burmese pythons, and may also help identify attractant baits for use as lures in traps.

\section{Methods}

Testing was conducted at the USDA/National Wildlife Research Center (NWRC), Fort Collins, Colorado, in the Invasive Species Research Building, a state-of-theart facility designed for research on such species. All research protocols were approved by the NWRC Institutional Animal Care and Use Committee.

The 8 Nile monitor lizards and 4 Burmese pythons (two males, two females) used in this study were acquired as juveniles in July 2007 from a commercial vendor (Ballroom Pythons South, Haines City, Florida). The Nile monitors had been caught in the wild, whereas the Burmese pythons were imported neonates which had been hatched in captivity. Sex was not determined in the Nile monitors because juveniles cannot be sexed by probe or visual inspection ( $T$. Campbell, DVM, Colorado State University, pers. comm.). The pythons were sexed by probing the hemipenes. Bait acceptance tests were conducted from April to October 2008.

Nile monitor lizards were housed individually, each in a 57 capacity aquarium $(60 \mathrm{~cm}$ long $\times 30 \mathrm{~cm}$ wide $\times 30 \mathrm{~cm}$ deep) with sheet paper bedding, a hide shelter from a PVC tube cut lengthwise, and a secured wire-mesh top. Additional heat was provided by a $15-\mathrm{W}$ heat lamp positioned above one end of the aquarium. Monitors were maintained one per room in an area physically separated from the pythons. The pythons were housed individually in one room in ventilated polycarbonate storage boxes $(66 \mathrm{~cm}$ long $\times 46 \mathrm{~cm}$ wide $\times 17 \mathrm{~cm}$ deep) with sheet paper bedding, a PVC tube refugium, and a secured lid. Additional heat was supplied by a $30-\mathrm{W}$ mylar substrate heater in each cage.

Water was provided ad libitum for each animal, and rooms for both species were maintained at about $30^{\circ} \mathrm{C}$ and $55 \%$ relative humidity with a $12 \mathrm{~h}$ light $/ 12 \mathrm{~h}$ dark photoperiod (lights on at $0600 \mathrm{~h}$, lights off at $1800 \mathrm{~h}$ ). Monitors were fed a DNM three times a week (the diet of one of the monitors was also supplemented with crickets, mealworms, or goldfish to promote feeding). Pythons were fed a DNM twice a week.

Nine non-toxic commercially available baits were tested: (1) DNM, (2) one-day-old dead coturnix quail (Coturnix coturnix) chicks, (3) coturnix quail eggs, (4) squid, (5) ground turkey, (6) chicken liver, (7) tilapia, (8) a dog snack (Pup-Peroni ${ }^{\circledR}$, Del Monte Pet Products, Pittsburgh, PA, USA; called "beef dog snack" for this study), and (9) Zebra finch (Taeniopygia guttata) eggs. Except for the egg and beef dog snack baits, all baits were maintained frozen (about $-22^{\circ} \mathrm{C}$ ), and thawed on the day that they were offered to the animals. Quail and zebra finch egg baits were refrigerated (about $2{ }^{\circ} \mathrm{C}$ ) and beef dog snack baits were stored at ambient laboratory room temperature (about $21^{\circ} \mathrm{C}$ ). Baits maintained under these conditions were termed "fresh" baits. Except for quail and zebra finch eggs, all baits approximated the size and shape of DNMs.

The 9 fresh baits were administered as 1-choice tests. Except for zebra finch eggs, each week, one each of the other 8 test baits was randomly assigned without replacement (www.randomizer.org/about.htm) to each of 8 individually caged Nile Monitor lizards and to each of 4 individually caged Burmese pythons. Thus, 
each bait-type was randomly presented once per animal per week for 8 weeks. Zebra finch eggs were not randomized, but offered singly to the lizards and pythons after each of the 8 randomized baits were tested. After a 48-h fast, baits were offered at about 0800 hours. Bait consumption was recorded at 2, 4, 6, 8 , and $24 \mathrm{~h}$ after presentation. Baits not consumed within $24 \mathrm{~h}$ were removed. Thus, for each bait test on each animal, observations were available on whether the bait was taken and the time interval in which it was taken.

Because DNM baits for brown tree snakes on Guam were shown to be attractive to snakes after aging for a day (Jojola-Elverum et al. 2001) we repeated the same tests using baits that had been aged for a day. Testing procedures were identical to those described above for the 1-choice tests with fresh baits, except all baits were first placed individually in an open glass jar at $30^{\circ} \mathrm{C}$ and $50 \%$ relative humidity (to simulate natural decomposition) for $24 \mathrm{~h}$ prior to being offered to the animals.

After testing was completed, all animals were euthanized with carbon dioxide and body mass ( $\mathrm{g}$ ) and snout-vent length (SVL, mm) recorded. At this time, the eight monitors ranged from 114.6 to $309.3 \mathrm{~g}$ in mass $(\bar{x}=238$, standard error $[\mathrm{SE}]=22.8)$ and 195 to $265 \mathrm{~mm}$ in SVL $(\bar{x}=237, \mathrm{SE}=8.1)$, and the four pythons ranged from 400.5 to $521.5 \mathrm{~g}$ in mass $(\bar{x}=475, \mathrm{SE}=26.0)$ and 928 to $1049 \mathrm{~mm}$ in $\mathrm{SVL}$ $(\bar{x}=988, \mathrm{SE}=25.8)$.

For those baits where both fresh and aged were well accepted (both $>50 \%$ acceptance), a Wilcoxon signed rank test was applied to see if one form was more rapidly accepted than the other.

\section{Results}

Acceptance rates of fresh and aged baits for Nile Monitor lizards and Burmese pythons are given in

Table 1. Acceptance rates of fresh and 1-day aged bait matrices for Nile monitor lizards (Varanus niloticus) and Burmese pythons (Python molurus bivittatus) in laboratory trials.

\begin{tabular}{lrrrrr}
\hline & \multicolumn{3}{c}{ Acceptance rate (\%) } \\
\cline { 2 - 3 } & $\begin{array}{c}\text { Nile monitor } \\
\text { lizards } \\
(n=8)\end{array}$ & & \multicolumn{2}{c}{$\begin{array}{c}\text { Burmese } \\
\text { pythons } \\
(n=4)\end{array}$} \\
\cline { 2 - 3 } \cline { 5 - 6 } Bait & Fresh & Aged & & Fresh & Aged \\
\hline Dead neonatal mouse & 87.5 & 75.0 & & 75.0 & 0.0 \\
Quail chick & 75.0 & 62.5 & & 75.0 & 50.0 \\
Beef dog snack & 0.0 & 12.5 & & 0.0 & 0.0 \\
Ground turkey & 75.0 & 87.5 & & 0.0 & 0.0 \\
Chicken liver & 62.5 & 87.5 & & 0.0 & 0.0 \\
Quail egg & 12.5 & 12.5 & & 0.0 & 0.0 \\
Tilapia & 87.5 & 87.5 & & 0.0 & 0.0 \\
Squid & 25.0 & 37.5 & & 0.0 & 0.0 \\
Zebra finch egg & 62.5 & 75.0 & 0.0 & 0.0 \\
\hline
\end{tabular}

Table 1. The array of baits accepted by Nile monitor lizards was much broader than that accepted by Burmese pythons. Nile monitors accepted all bait types at least once (either as fresh, aged, or both). Six of the nine bait types had acceptance rates that ranged from $63 \%$ to $88 \%$ (DNM, dead quail chick, ground turkey, chicken liver, tilapia, and zebra finch egg). Acceptance rates for three of these baits (DNM, ground turkey, and tilapia) ranged from $75 \%$ to $88 \%$. Of the six bait matrices that were well accepted by Nile monitors both as fresh and aged, only DNM showed a detectable difference in how rapidly the baits were consumed $(P=0.062)$. Median times to consumption of fresh and aged DNM baits were $<2 \mathrm{~h}$ and $>8 \mathrm{~h}$, respectively.

The only two baits accepted by the Burmese pythons were the whole natural animal baits, namely DNM and dead quail chick. Both were well accepted as fresh baits $(75 \%)$, but only quail chicks were consumed as aged baits $(50 \%)$. Pythons did not consume any of the other seven bait matrices.

\section{Discussion}

The most common bait preference studies concern the development of rodenticides that are used worldwide (Miller 1974; Rowe et al. 1974; Buckle and Kaukeinen 1988; Marsh 1988; Suliman et al. 1984; Witmer et al. 1995, 2008). With the exception of the brown tree snake, which caused the extirpation of most of Guam's native forest avifauna (Savidge 1987), few other species of invasive reptile have proven deleterious enough to warrant development of baits. The feeding ecology of $V$. niloticus (Bennett 2002) and feeding behavior of captive Varanus spp. has been studied (Loop 1974; Brown et al. 2003; Firth et al. 2003), but the present study is only the second one of which we are aware that has evaluated baits for delivery of potential control agents to reptiles. The first such study was successful in developing DNM as a bait for brown tree snakes (Savarie and Clark 2006), and field application of acetaminophen-treated DNM for snake control (Savarie et al. 2001).

That the Nile monitors readily accepted a variety of bait matrices, both fresh and aged, is not surprising since they are known to consume a varied carnivorous diet in nature (e.g. Enge et al. 2004; Campbell 2005; Meshaka 2006). However, Burmese pythons are also generalist carnivores, but did not accept the variety of baits that the monitors accepted, especially when aged. Besides the obvious inherent differences among different taxonomies, another contributing factor might be the comparative life histories of these particular animals. As previously stated, the pythons originated as neonates hatched in captivity, and the only prey items they had known were DNMs. The monitors, however, were caught in the wild and presumably had experience of foraging for diverse prey. This prior 
experience may have contributed to their willingness to accept varied baits.

An unanticipated result for the Nile monitors was that tilapia was well accepted, but squid was not. This is contrary to the findings of Campbell (2005) who found squid to be by far the best bait (lure) for trapping, with only minor attraction produced by mullet, chicken meat, and chicken eggs. There could be a variety of explanations for this, including that Campbell (2005) was using baits to lure Nile monitors into a trap, whereas our objective was to induce consumption. Also, Campbell (2005) was addressing a spectrum of size and age classes of wild Nile monitors, whereas our lizards were 1-1.5-year-olds that were caught in the wild but reared in captivity. In accordance with our findings, USDA/Wildlife Services operational personnel at Homestead Air Reserve Base, who occasionally trap and shoot Nile monitors to prevent potential airstrike hazards due to their basking on runways (see Engeman et al. 2005 on large invasive lizards as airstrike hazards), also found squid to be relatively ineffective, but have had success with chicken meat (W. Shockley, T. Hairston, personal communication; unreferenced). When the Cape Coral Environmental Resource Department attempts to trap Nile Monitors, chicken meat (backs) is used to bait the traps (H. Phillips, personal communication; unreferenced). The Homestead and Cape Coral populations are on opposite sides of the Florida peninsula in different habitats, with the Cape Coral lizards in a more urban setting. Also, no genetic testing has been done to determine relatedness of the two populations, so it is possible that preferences could be origin dependent.

Nile monitors are also known to eat eggs in the wild (Branch 1998; Enge et al. 2004), but Campbell (2005) found that chicken eggs were not a good lure for trapping. We had mixed results in that zebra finch eggs were reasonably well accepted, but quail eggs were not. Zebra finch eggs are about half the diameter of quail eggs and may have been consumed more readily simply because their smaller size made them more easily manipulated for eating. Eggs in nests of wild birds would be associated with a greater array of scents, including those of the monitor's potential prey, possibly producing a greater attraction. One lesson from the present study is that there is value in having multiple bait matrices available based on lab and field tests, with the bait(s) most suitable for a particular application being determined before commencing operational control.

The Burmese pythons clearly preferred natural prey items and seemed more selective than brown tree snakes in similar bait testing trials (Savarie and Clark 2006). The implications are that baits for wild Burmese pythons in Florida would be better based on whole animal baits. Aging decreased the acceptance of the two bait matrix types accepted by Burmese pythons, contrary to field study observations on brown tree snakes where acceptance of aged DNM was higher than fresh DNM (Jojola-Elverum et al. 2001). However, snakes under field conditions may not necessarily prefer aged DNM; more likely, they are better able to locate aged DNM because of their increased odor plume. However, pythons in the wild might display a very different acceptance of carrion than do captive animals, and this potential should be further investigated. Such work would also provide information on the length of time baits would remain attractive to pythons in the field.

There are four processes involved in developing useful toxic baits for field application: (1) identification of bait matrices accepted by the target animal; (2) identification of a toxicant effective towards the target animal; (3) identification of delivery mechanisms and strategies that effectively present the bait to the target animal while excluding non-target species; and (4) in the United States, registration with the Environmental Protection Agency. This paper focuses on identification of bait matrices accepted by Nile monitors and Burmese pythons, while Mauldin and Savarie (2010) addressed the identification of a toxicant for both species. Thus, finding a compound that is toxic to Nile monitors and Burmese pythons and an acceptable bait matrix (or matrices) are only the first two steps in developing a practical, effective, and legal baiting strategy. The critical third step is to develop a mechanism and placement strategy that would deliver the bait specifically to the target species and prevent take by native, non-target species.

While our paper addresses acceptance tests of bait matrices, we can look ahead towards some considerations for developing delivery mechanisms. In Florida there are many species that would have to be prevented from accessing or consuming toxic baits. These would include various species of concern such as the Eastern Indigo snake (Drymarchon corais couperi Schmidt), as well as common species of many taxa. Assuming acetaminophen is the selected toxicant, little is known about its toxicity to most species, and it has not been consistently toxic among the four reptile species upon which it has been tested. As indicated, it is toxic to brown tree snakes (Savarie et al. 2001) and Mauldin and Savarie (2010) showed it to be toxic to Nile monitors and Burmese pythons, but in recent lab trials it was found inadequately toxic towards black spinytailed iguanas (Ctenosaura similis [Gray]) to consider for control purposes (Avery et al. 2011). Nevertheless, bait delivery development for Nile monitors and Burmese pythons would have to focus on excluding non-target species. Besides toxicity, there are other non-target species considerations that could affect successful bait usage. For example, raccoons (Procyon lotor) would be among the non-target species most likely to consume the baits identified in the present study. They are ubiquitous in Florida, often at high densities (Smith and Engeman 2002), and if not prevented from accessing baits could cause sufficient 
bait loss as to render a baiting program inefficient or ineffective. The importance and approaches for using delivery methods that avoid non-target species have been discussed extensively in Mauldin and Savarie (2010).

All of the bait matrices we tested are commercially available, a condition essential for a practical operational baiting program. Using these results as a foundation, trials are now warranted to evaluate consumption of candidate bait matrices by both Nile monitors and Burmese pythons under field conditions.

\section{Declaration}

All work conformed to the applicable federal and state legal requirements. Including those related to conservation and welfare of animals, with the research protocol QA-1539 reviewed and approved by the National Wildlife Research Center Institutional Animal Care and Use Committee.

\section{Disclaimer}

Use of a trade name does not constitute endorsement by the USA government.

\section{Acknowledgements}

We thank the Animal Care Staff at the National Wildlife Research Center for their efforts in accommodating and caring for these animals. We appreciate the efforts of G. Gathright and D. Gossett during the post-mortem examination of the animals. We thank W. Shockley and T. Hairston for information on Nile monitor trapping methods on site visits at Homestead Air Reserve Base, Florida. We also thank H. Phillips for Nile monitor trapping information at Cape Coral, Florida.

\section{References}

Avery ML, Eisemann JD, Keacher KL, Savarie PJ. 2011. Acetaminophen and zinc phosphide for lethal management of invasive lizards Ctenosaura similis. Curr. Zool. 57:625-629.

Bayless MK. 1991. A trip from Africa. VaraNews. 1:5-8.

Bennett D. 1995. A little book of monitor lizards. Glossop, (UK): Viper Press.

Bennett D. 2002. Diet of juvenile Varanus niloticus (Sauria: Varanidae) on the Black Volta River in Ghana. J Herpetol. 36:116-117.

Bilger B. 2009. Swamp things. New Yorker. 85:80-89.

Branch B. 1998. Field guide to snakes and other reptiles of Southern Africa. Sanibel Island (FL): Ralph Curtis Books and Publishing.

Brown C, Foster C, Spivey-White J, Hesletine J. 2003. Feeding behaviour in monitor lizards and snakes; does direction of prey ingestion influence prey handling time? Herpetol Bull. 83:26-29.

Buckle AP, Kaukeinen DE. 1988. A field method for assessing the palatability of rodenticidal baits. Vertebrate Pest Conference. 13:156-159.

Campbell TS. 2005. Eradication of introduced carnivorous lizards from the Cape Coral area. Final report to the Charlotte Harbor National Estuary Program, 1926 Victoria Avenue, Ft Myers, Florida 33901. p. 30.
Enge KM, Krysko KL, Hankins KR, Campbell TS, King FW. 2004. Status of the Nile monitor (Varanus niloticus) in southwestern Florida. Southeastern Naturalist. 3:571-582.

Engeman RM, Constantin BU, Hardin S, Smith HT, Meshaka WE., Jr. 2009. "Species pollution" in Florida: a cross-section of invasive vertebrate issues and management responses. In: Wilcox $\mathrm{CP}$, Turpin $\mathrm{RB}$, editors. Invasive species: detection, impact and control. Hauppauge (NY): Nova Science Publishers. p. 179-197.

Engeman RM, Smith HT, Constantin BU. 2005. Invasive Green Iguanas as airstrike hazards at San Juan International Airport, Puerto Rico. J. Aviation-Aerospace Educ. Res. 14:45-50.

Engeman RM, Vice DS. 2001. Objectives and integrated approaches for the control of brown tree snake. Integ Pest Manage Rev. 6:59-76.

Faust RJ. 2001. Nile monitors: everything about history, care, nutrition, handling, and behavior. Hauppauge (NY): Barron's Educational Series.

Firth I, Turner M, Robinson M, Meek R. 2003. Response of monitor lizards (Varanusspp.to a repeated food source; evidence for association learning? Herpetol Bull. 84:1-4.

Florida Fish and Wildlife Conservation Commission. 2011. http://myfwc.com/wildlifehabitats/nonnatives/reptiles/nilemonitor/ (accessed 30 August 2011).

Greene DU, Potts JM, Duquesnel JG, Snow RW. 2007. Geographic distribution: Python molurus bivittatus (Burmese python). Herpetol Rev. 38:355.

Hardin S. 2007. Managing non-native wildlife in Florida: state perspective, policy and practice. In: Witmer G, Pitt W, Fagerstone K, editors. Managing vertebrate invasive species: proceedings of an international symposium. Fort Collins (CO): USDA/APHIS/WS, National Wildlife Research Center. p. 43-54.

Jojola-Elverum SM, Shivik JA, Clark L. 2001. Importance of bacterial decomposition and carrion substrate to foraging brown treesnakes. J Chem Ecol. 27:1315-1330.

Lenz S. 2004. Varanus niloticus. In: Pianka ER, King DR, editors. Varanoid lizards of the world. Bloomington (IN): Indiana University Press. p. 132-133.

Loop MS. 1974. The effect of relative prey size on the ingestion behavior of the Bengal monitor, Varanus bengalensis (Sauria: Varanidae). Herpetologica. 30:123127.

Marsh R. 1988. Bait additives as a means of improving acceptance by rodents. EPPO Bull. 18:195-202.

Mauldin RE, Savarie PJ. 2010. Acetaminophen as an oral toxicant for Nile monitor lizards (Varanus niloticus) and Burmese pythons (Python molurus bivitattatus). Wildlife Res. 37:215-222.

Meshaka WE. 2006. An update on the list of Florida's exotic amphibians and reptile species. J Kansas Herpetol. 19:16-17.

Meshaka WE, Butterfield BP, Hauge JB. 2004. The exotic amphibians and reptiles of Florida. Malabar (FL): Krieger Publishing Company.

Meshaka WE, Jr, Loftus WF, Steiner T. 2000. The herpetofauna of Everglades National Park. Florida Scientist. 63:84-103.

Miller JG. 1974. The significance of preference in laboratory bait acceptance studies. Vertebrate Pest Conference. 6:78-81.

Minton SA, Minton MR. 1973. Giant reptiles. New York: Charles Scribner's Sons.

Rowe FP, Bradfield A, Redfern R. 1974. Food preferences of wild house-mice (Mus musculus L.). J Hygiene. 73:473-478.

Savarie PJ, Shivik JA, White GC, Hurley JL, Clark L. 2001. Use of acetaminophen for large-scale control of brown treesnakes. Journal of Wildlife Management. 65:356-365. 
Savarie PJ, Clark L. 2006. Evaluation of bait matrices and chemical lure attractants for brown treesnakes. Vertebrate Pest Conference. 22:483-488.

Savidge JA. 1987. Extinction of an island avifauna by an introduced snake. Ecology. 68:660-668.

Smith HT, Engeman RM. 2002. An extraordinary raccoon density at an urban park in Florida. Can Field Naturalist. 116:636-639.

Smith HT, Sementelli A, Meshaka WE, Jr, Engeman RM. 2007. Reptilian pathogens of the Florida everglades: the associated costs of Burmese pythons. Endangered Species Update. 24:63-71.

Snow RW, Brien ML, Cherkiss MS, Wilkins L, Mazzotti FJ. 2007a. Dietary habits of the Burmese python, Python molurus bivittatus, in Everglades National Park, Florida. Herpetol Bull. 101:5-7.

Snow RW, Krysko KL, Enge KM, Oberhofer L, WalkerBradley A, Wilkins L. 2007b. Introduced populations of Boa constrictor (Boidae) and Python molurus ivittatus (Pythonidae) in southern Florida. In: Henderson RW, Powell R, editors. The biology of boas and pythons. Eagle Mountain (UT): Eagle Mountain Publishing. p. 416-438.
Suliman SM, Shumake SA, Jackson WB. 1984. Food preference in the Nile rat Arvicanthis niloticus. Trop Pest Manage. 30:151-158.

Western D. 1974. The distribution density, and biomass density of lizards in a semi-arid environment of northern Kenya. East African Wildlife J. 12:49-62.

Witmer GW, Fall MW, Fiedler LA. 1995. Rodent control, research needs, and technology transfer. In: Bissonette A, Krausman PR, editors. Integrating people and wildlife for a sustainable future. Proceedings of the first International Wildlife Management Congress. Bethesda (MD): The Wildlife Society. p. 693-697.

Witmer G, Burke P, Jojola S. 2008. An evaluation of the effectiveness of potential Norway rat attractants. Vertebrate Pest Conference. 23:35-38. 